\title{
Unemployment of Non-western Immigrants in the Great Recession
}

\author{
Jakub Cerveny* Jan C. van Ours ${ }^{\dagger}$
}

September 21, 2013

\begin{abstract}
This paper examines whether unemployment of non-western immigrant workers in the Netherlands was disproportionally affected by the Great Recession. We analyze unemployment data covering the period November 2007 to February 2013 finding that the Great Recession affected unemployment rates of non-western immigrant workers in absolute terms more than unemployment rates of native workers. However, in relative terms there is not much of a difference. We also find that the sensitivity of individual job finding rates to the aggregate state of the labor market does not differ between natives and non-western immigrants. In combination our findings suggest that the Great Recession did not have a different impact on the unemployment of non-westerns immigrants and native Dutch.
\end{abstract}

Keywords: Great Recession, unemployment, non-western immigrants

JEL-codes: J15, J64

\footnotetext{
*Department of Economics, Tilburg University, The Netherlands; jakub@localhost.sk

$\dagger$ Department of Economics, CentER, Tilburg University, The Netherlands; Department of Economics, University of Melbourne, Parkville, Australia; CEPR (London), CESifo (Munich), IZA (Bonn); vanours@uvt.nl.

${ }^{\ddagger}$ The authors thank Rob Alessie for useful comments.
} 


\section{Introduction}

The labor market position of immigrants in many European countries is weak; unemployment rates among immigrants are high, employment rates are low (Boeri and van Ours (2013), OECD (2011)). There are various explanations for this. Immigrants often have a lower educational attainment than natives, and fewer language skills. Furthermore, ethnic identity, age at immigration and location may be important. Algan, Dustmann, Glitz, and Manning (2010) study the economic situation of immigrants in France, Germany and the United Kingdom in terms of education and labor market performance. They conclude that immigrant children have lower gaps in education than their parents because the education systems seems to integrate the children of immigrants. For labor market performance, they do not find similarly marked evidence of progress. Nice overviews of the educational attainment of immigrants and immigrant children are Dustmann and Glitz (2011) while Dustmann et al. (2012) give an interesting overview of the educational attainment of second-generation immigrants. Bisin, Patacchini, Verdier, and Zenou (2011) find that ethnic identity and labor market outcomes of non-EU immigrants in Europe are related. Immigrant children have a higher probability of being employed than their parents and, compared to natives, there does not seem to be any difference in terms of employment. The authors relate this to an economic integration process of immigrants. Recent research shows that also the location of immigrants matters. Edin, Fredriksson, and Aslund (2003) analyze the labor market position of refugee immigrants in Sweden showing that living in enclaves improves labor market outcomes of less-skilled immigrants compared to immigrants living outside enclaves. Damm (2009) finds that in Denmark, refugees with unfavorable unobserved characteristics self-select into immigrant enclaves. She also finds that living in an enclave is beneficial to immigrant wages.

When considering the labor market position of immigrants, an important distinction is between western and non-western immigrants. Whereas in many European countries the labor market position of western immigrants is very much the same as for natives, the labor market position of non-western immigrants is ofter worse. Our paper does not study the extent to which the labor market position of non-western immigrants is better or worse than the labor market position of natives. The Great Recession after its outburst in late 2008 had profound impacts on the world economy, affecting also labor markets causing unemployment to increase rapidly. We study whether recent events affected non-western immigrants more than natives. Not much research has been done on this. An exception is the study by Dustmann, Glitz, and Vogel (2010). They analyze differences in the pattern of employment and wages of immigrants and natives for two large immigrant receiving 
countries, Germany and the UK. They distinguish between immigrants from OECD and non-OECD countries. Their results suggest larger unemployment responses to economic shocks for immigrants relative to natives. These differences are particularly pronounced for non-OECD immigrants, and evident for both Germany and the UK, despite their rather different immigrant populations. However, between natives and immigrants there seems to be only a small difference in wage responses to economic shocks.

In the Netherlands, initially during the Great Recession unemployment stayed relatively low but in recent years unemployment is increasing. ${ }^{1}$ The current paper addresses the question whether the effect of the Great Recession on the labor market position of non-western immigrants in the Netherlands has been different from the effect on the labor market position of natives. In our analysis we use labor market data covering the period November 2007 to February 2013. We confirm that the labor market position of nonwestern immigrant workers in the Netherlands is weak with high unemployment rates and low employment rates. We find that the Great Recession affected unemployment rates of non-western immigrant workers in absolute terms more than unemployment rates of native workers. However, in relative terms there is not much of a difference in sensitivity. We also find that the sensitivity of individual job finding rates does not differ between natives and immigrants. Apparently, the Great Recession did not have a different impact on the unemployment of non-western immigrants and natives.

The remainder of this paper is organized as follows. The following section provides a characterization of the immigrant population in the Netherlands and a description of the evolution of employment rates and unemployment rates in Netherlands over the past decade, distinguished by gender, age and immigrant status. Section 3 gives a description of the dataset we use in our analysis. Section 4 provides an analysis of the cyclical sensitivity of being unemployed. Section 5 studies how individual unemployment durations are affected by aggregate unemployment rates. Section 6 concludes.

\section{Immigrants in the Dutch labor market}

\subsection{Background}

In Dutch population statistics a distinction is made between immigrants from western countries such as Europe, North America and Oceania and immigrants from non-western countries. Over the past decades, migrants from non-western countries came to the Netherlands broadly for the three reasons, because of the independence of former colonies,

\footnotetext{
${ }^{1}$ For an overview of recent developments in the Dutch labor market see Van Ours (2012).
} 
because of labor shortage and because of political turmoil in their home country (Van Ours and Veenman (2005)). Firstly, in the decades after the Second World War large groups of immigrants came from Indonesia, Surinam, and the Antilles. Secondly, in the 1960s and early 1970s workers were recruited mainly from Turkey and Morocco to fill vacancies for unskilled labor in a booming Dutch economy. In later decades immigration from Turkey and Morocco continued as a consequence of family unification and family formation. In recent years, political refugees and asylum seekers entered the Netherlands. After the fall of the Soviet Union, many immigrants from Eastern Europe moved to the Netherlands. In more recent years, economic and political crises have increased the flow of immigrants from diverse backgrounds such as Iraq, Iran, Afghanistan, and Somalia.

January 1, 2013 the Dutch population of 16.8 million consisted of 13.3 million native Dutch, 1.5 million western immigrants and 2.0 million non-western immigrants. The largest western immigrant groups are from Germany (370,000), Belgium (100,000) and Poland (100,000). The largest non-western immigrant groups are from Turkey $(400,000)$, Morocco (370,000), Surinam (350,000) and the Antilles $(150,000)$. The labor market position of western immigrants is similar to the labor market position of natives while non-western immigrants perform worse. According to Statistics Netherlands, in the first quarter of $201375 \%$ of the native population of working age (16 to 65 years) had a job. Among western immigrants this was $71 \%$ while among non-western immigrants it was $56 \%$. Also in terms of unemployment rates as a percentage of the labor force the position of non-western immigrants is very different. Whereas in the first quarter of 2013 the unemployment rate among natives was $6.4 \%$ and among western immigrants it was $8.2 \%$, it was $19.2 \%$ among non-western immigrants. Because western immigrants do not differ much from natives in terms of their labor market position, we focus on differences in labor market performance between natives and non-western immigrants in response to the Great Recession.

As in other European countries, non-western immigrants have a lower educational attainment than natives. Van Ours and Veenman (2003) find evidence that the gap in educational attainment between the young natives and young immigrants is smaller for the second-generation immigrants than the first-generation immigrants. Van Ours and Veenman (2006) present evidence that the educational attainment of non-western immigrants depends on their age at immigration (see also Cortes (2006)). Ohinata and van Ours (2012) investigate the differences in test scores, between immigrant children in the Netherlands and native Dutch children conditional on personal and family characteristics and classroom environment. They also highlight the differential educational achievements 
by first and second-generation immigrants. Moreover, for the first-generation immigrants, they study whether the age at immigration influences the academic achievements. They find that immigrant children aged 9 and 10 perform worse in terms of science test-scores and maths test-scores compared to native Dutch children whereas almost no significant differences are found for reading test-scores. The negative performance is observed particularly among the first-generation immigrant children. Age at immigration is important particularly for immigrant children born from two immigrant parents. Van Ours and Veenman (2004) study early labor market experiences of second-generation immigrants in the Netherlands. They focus on the four main non-western immigrant groups. From a direct comparison it appears that especially Turkish and Moroccan immigrant children are not performing as well as native Dutch youngsters. Young Surinamese and Antilleans are also doing worse than their Dutch counterparts, but for them the differences are smaller. When leaving school the average educational level of these ethnic groups is lower, the participation in the labor market is lower and if they participate in the labor market they are less likely to have a job.

\section{$2.2 \quad$ Recent developments}

The labor market position of non-western immigrant workers over the past decade is characterized in Figures 1 and 2. Figure 1 plots employment trends for three age categories, young (15-24 year old), prime age (25-54), and older workers (55-65), distinguishing between native and non-western immigrant male and female workers. As can be seen, there are clear cycles for all age categories, with a drop in employment in the years 2004-2005, and another fall after the outbreak of the Great Recession in late 2008. Nevertheless, the numbers still remain high for the prime age category of 25-54 years, with employment rates between 90-95\%. The difference between native Dutch and non-western immigrant workers is evident, spanning almost $20 \%$ in the prime category, where the employment rate of immigrant men is close to the rates of native women. This gap is narrower only for women in the category of 55-65 years old. Compared to prime age workers, employment rates are substantially lower for younger and older men. For young men there is a clear decline in the employment rate, while for older men there is a strong increase. This increase in the employment rate for older workers may be related to the abolition of early retirement programs.

As shown in Figure 2, the differences between non-western immigrants and natives are substantial also in terms of unemployment rates. The gap is almost $10 \%$ in all age categories, and slightly higher for the youngest workers. In this category, every fourth 
young immigrant worker is unemployed. Moreover, immigrants seem to be much more prone to cyclical fluctuations. The 2004-2005 shock affected both native men and women only slightly, whereas unemployment rates of immigrants rocketed by almost 10\%-point.

\section{Data}

The datasets we use in our analysis are the LISS panel and the LISS immigrant panel. These internet based household surveys were conducted in The Netherlands in the period November 2007 to February 2013. The LISS panel (Longitudinal Internet Studies for the Social sciences) is the principal component of the MESS project (Measurement and Experimentation in the Social Sciences). It consists of 5000 households, comprising almost 8000 individuals. The panel is based on a sample of households drawn from the population register by Statistics Netherlands. Households that could not otherwise participate are provided with a computer and Internet connection. A special immigrant panel is available in addition to the LISS panel. This immigrant panel is comprised of around 1600 households (2400 individuals) of which 1100 households (1700 individuals) are of non-Dutch origin. Panel members complete online questionnaires every month of about 15 to 30 minutes in total. They are paid for each completed questionnaire. One member in the household provides the household data and updates this information at regular time intervals.

Every month household members are asked various questions regarding their occupation, income, civil status, age etc. From December 2010 onwards, one of the questions added was immigrant status, with possible indications of Dutch origin, first generation immigrant with western background or non-western background, second generation immigrant with western background or non-western background. Therefore, we were able to identify earlier responses than December 2010 in the panel and match them with their respective origin. Nevertheless, because the immigrant status was introduced late we have quite a few missing observations for this variable. To illustrate how sensitive our results are to the inclusion of this variable we present estimates with and without immigrant status. We do not make a distinction between first generation and second generation immigrants.

In each of the waves the respondents indicated whether they were unemployed or employed. Answers indicating that a person was pensioner or (partial) work disabled were treated as missing values. Thus we have a dataset consisting of 12,090 individuals of whom we have in total 429,243 monthly observations about the employment- 
unemployment status (see the Appendix for details). For the purpose of analyzing the duration of unemployment we created a inflow-into-unemployment sample consisting of 1134 observations. Each of these observations refer to an unemployment spell that started somewhere in the period November 2007 to January 2013.

Figure 3 plots the evolution of unemployment rates as measured in the LISS-panel. As can be seen, the development of unemployment rates corresponds to the developments in the Dutch labor market during observation period. At the beginning of the year 2009, the unemployment rates started to rise. The unemployment rate of the native workers went up from 5 to $8 \%$, the unemployment rate of non-western immigrant workers went up from 12 to $20 \%$. In absolute terms there is a big difference in the increase in unemployment. However, as Figure 3 suggests, in relative terms the increase was comparable.

\section{Probability to be unemployed}

In order to investigate the differences between native and non-western populations, we begin by evaluating the large LISS monthly panel dataset. We estimate the following model:

$$
U_{i \tau}=u_{\tau} \gamma+\alpha_{i}+\varepsilon_{i \tau}
$$

where $U_{i \tau}$ denotes whether or not an individual $i$ is unemployment in calendar month $\tau$, $u_{\tau}$ represents the aggregate unemployment rate in month $\tau$, the $\alpha_{i}$ represent individualspecific fixed effects and for the idiosyncratic error term we assume $E\left(\varepsilon_{i \tau} \mid u_{\tau}, \alpha_{i}\right)=0$. The parameter $\gamma$ is the parameter of main interest, indicating how aggregate unemployment rates affect individual unemployment probabilities.

The parameter estimates of the fixed effects linear probability models are shown in panel a of Table 1 where in the first row there is no distinction in immigrant status while in the second and third row separate estimates for natives and immigrants are reported. The first column shows the estimates for the full sample. Clearly an increase in the national unemployment rate has a positive effect on the individual probability to be unemployed. An increase in the national unemployment rate of 1\%-point causes the individual probability of being unemployed to go up with $0.72 \%$-point. ${ }^{2}$ The second column shows parameter estimates for the sub-sample of natives and non-western immigrants. Now the effect of the aggregate unemployment rate is slightly larger. The

\footnotetext{
${ }^{2}$ Note that the national unemployment rate is based on a definition that takes the hours of work into account. If an individual works less than 12 hours per week but would like to work more than 12 hours per week this individual is considered to be unemployed. In our dataset we do not make such a distinction according to hours of work.
} 
third column shows that for prime age workers the effect of national unemployment rate on individual unemployment probability is slightly lower. The second and third row of panel a show separate cyclical effects for natives and immigrants. Clearly the cyclical effect is substantially larger for non-western immigrant workers. An increase in the aggregate unemployment rate causes the unemployment probability for natives to go up with $0.77 \%$-point while for non-western immigrants this probability goes up with $1.64 \%$ points. ${ }^{3}$ However, these are absolute effects of unemployment rates on the probability of being unemployed. Panel b of Table 1 shows that there is a substantial difference in the probability of being unemployed for natives and immigrants. Clearly, the labor market position of immigrants is substantially worse than of natives. The probability to be unemployed over the sample period was about 16 to $18 \%$ for immigrant workers while for native workers it was on average $6.2 \%$ for all ages and $3.8 \%$ for prime age workers. Panel c shows the results of a normalization of the effects estimated in panel a. Here, we divide the estimated effect in panel a by the unemployment probability presented in panel $\mathrm{b}$ and multiplying this by 100 . The parameters in panel $\mathrm{c}$ show the relative effect on the unemployment probability of individual workers of a 1\%-point increase in the national unemployment rate. Now, there is not much of a difference between natives and immigrants. For example for prime age immigrant workers the effect of a 1\%-point increase in the national unemployment rate is a relative increase of $9.3 \%$, while for prime age natives this is $13.4 \%$.

\section{Unemployment durations}

\subsection{Set-up of the analysis}

To analyze the determinants of unemployment durations we use a hazard rate framework in which we focus on job finding rates. The top graph of Figure 4 gives an idea about the magnitude of the monthly job finding rates of prime age workers and their evolution over the duration of unemployment. In the calculation of the job finding rates we take into account that a substantial part of the unemployment durations is right censored, i.e. they are incomplete. Furthermore, we treat durations ending with a transition out of the labor force or into disability as right censored. As shown, in the initial part of the unemployment spell the monthly job finding rate is about $12 \%$ for native unemployed

\footnotetext{
${ }^{3}$ The cyclical effect for western immigrants is about the same as for native workers. For workers with an unknown immigrant status the cyclical effect is smallest. This may have to do with the fact that workers with an unknown immigrant status are observed only in the first years of the sample when unemployment rate did not vary so much.
} 
and about $7 \%$ for non-western immigrant unemployed. There is a decline in both job finding rates over the duration of unemployment. The bottom graph of Figure 4 shows survival probabilities over the first two years of the unemployment spell. After 2 years of unemployment about $50 \%$ of the non-western immigrants is still unemployed, while this is about $20 \%$ for native unemployed. Clearly the average unemployment spell last substantially longer for non-western immigrants than it does for natives.

To investigate the job finding rates, we use a proportional hazard rate model in which the rate by which unemployed workers find a job at duration $t$ conditional on observed characteristics $x$ has a multiplicative specification (omitting a subscript for individual):

$$
\theta\left(t \mid x, u_{0}, u_{t}\right)=\lambda(t) \exp \left(x^{\prime} \beta+\delta_{1} u_{0}+\delta_{2}\left(u_{t}-u_{0}\right)\right)
$$

where $u_{0}$ represents the national unemployment rate at the start of the unemployment spell, $u_{t}$ is the national unemployment rate in duration month $t$, and $\lambda(t)$ captures the baseline duration dependence of the job finding rate. Furthermore, $\beta$ is a vector of parameters and the parameters $\delta_{1}$ and $\delta_{2}$ are the parameters of main interest. Duration dependence is specified as a piecewise constant function of elapsed duration as follows:

$$
\lambda(t)=\exp \left(\sum_{l} \lambda_{l} I_{l}\right)
$$

where $I$ is an indicator function for duration intervals $l$ specified for $0-3,4-6,7-9,10-12$, 13-18, 18+ months of unemployment. The $\lambda_{l}$ parameters represent the pattern of duration dependence. In the estimates we focus on the first two years of unemployment assuming that all spells that go beyond 2 years are right-censored at 24 months. Individuals who were still unemployed in February 2013 were considered to have right-censored unemployment durations. Unemployment spells that ended in a transition to a labor market state other than a job were also considered to be right-censored.

The conditional density function for completed durations of unemployment can be written as:

$$
f\left(t \mid x, u_{0}, u_{t}\right)=\theta\left(t \mid x, u_{0}, u_{t}\right) \exp \left(-\int_{0}^{t} \theta\left(s \mid x, u_{0}, u_{t}\right) d s\right)
$$

\subsection{Parameter Estimates}

The top part of Table 2 shows the parameter estimates. Column (1) reports estimates for the full sample in which the immigrant status is not known for all individuals, column (2) shows the parameter estimates for the sample for whom immigrant status is known 
and we can distinguish between natives and non-western immigrants. In column (3) the sample is restricted to prime age (25-54 years) natives and non-western immigrants. The first column shows that both the unemployment rate at the time of the start of the unemployment spell as well as the unemployment rate over the duration of unemployment have negative effects on the job finding rates. Unemployed workers who enter unemployment at times of high unemployment face a longer unemployment spell. A 1\%-point increase in the national unemployment rate causes the job finding rate to go down with about $20 \%$ $(100 * \exp (-0.23)-100)$. In addition to that, if unemployment increases over the duration of the unemployment spell, the job finding rates are further reduced. A 1\%-point increase in the national unemployment rate over the course of unemployment causes the job finding rate to go down with about $30 \%(100 * \exp (-0.37)-100)$. Furthermore, we find unemployed with the lowest educational attainment to have the lowest job finding rates. Whether or not unemployed have children and whether they are male or female does not have a significant effect on their job finding rates. In terms of age, the highest job finding rates are for unemployed in the age category 45 to 54 , while the lowest job finding rates are for unemployed in the age category 55 to 64 years. Finally, the job finding rates go down over the duration of unemployment.

The second column of Table 2 shows the parameter estimates of the restricted sample for individuals of whom the immigrant status is known. Job finding rates for non-western immigrants are substantially below those for native unemployed workers. The unemployment rate at the time of the start of the unemployment spell has a significantly negative effect on the job finding rates of native unemployed and a positive but insignificant effect on the job finding rates of immigrant workers. The unemployment rate over the duration of the unemployment has a negative effect too. The parameter estimate is the same for natives and non-western immigrants although the estimate for immigrant workers is significantly only at the $10 \%$ level. Column (2) of panel b shows what happens if we impose the effects of the unemployment rate to be the same for natives and non-western immigrants. Then the parameter estimates are not very different from those in column (1). From a likelihood-ratio test it appears that we cannot reject the hypothesis that the effects are the same for natives and non-western immigrants. ${ }^{4}$ With respect to the other parameter estimates there is not a lot of difference between column (1) and column (2). The third column of Table 2 shows the parameter estimates for the sample of prime age workers. The results are not much different from the parameter estimates in the first two columns.

\footnotetext{
${ }^{4}$ The LR-test statistic is equal to 3.8 , while the critical $\chi^{2}$ value with 2 degrees of freedom is equal to 6.0
} 
Table 3 shows additional parameter estimates. The first column shows the parameter estimates for men only. By and large the results are the same as before. Non-western immigrants perform worse and there is no difference in the effects of unemployment rates for non-western immigrants and natives. The same holds for the parameter estimates in the second column which are based on the sample of women only. The main difference is that the cyclical effects of the unemployment rates are smaller and not always significantly different from zero. Finally, the third column of Table 3 shows the parameter estimates if we allow for the effects of unobserved heterogeneity to influence the job finding rate. In the Mixed Proportional Hazard (MPH) specification we introduce random effects, i.e. a mass point distribution with two points of support. Only at a $10 \%$ level there is a significant improvement of the overall estimation results. And, what is perhaps more important, the main conclusions derived from the proportional hazard model are not affected. National unemployment rates affect individual job finding rates both at the start of the unemployment spell as well as during the unemployment spell. There is no difference between these effects for non-western immigrants and natives.

\section{Conclusions}

We study the impact of the Great Recession on unemployment of native and non-western immigrant workers in the Netherlands. In the beginning of the century, the overall labor market situation was good, with high employment rates and low unemployment rates. Between 2003 and 2005 unemployment rates increased. In subsequent years there was a slight recovery after which the Great Recession caused unemployment rates to go up substantially. We find that the Great Recession affected unemployment rates of immigrant workers in absolute terms more than unemployment rates of native workers. Between 2008 and 2012 unemployment rates for prime age native workers increased with 3 percentage-points from 2 to 5 percent of the labor force. For prime age immigrant workers unemployment rates increased with 8 percentage-points from 7 to 15 percent of the labor force. However, in relative terms there is not much of a difference between the cyclical sensitivity of unemployment rates of non-western immigrants and natives. Job finding rates are much lower for non-western immigrants than they are for native workers. The national unemployment rate also affects individual job finding rates. A high unemployment rate at the start of the unemployment spell has a negative effect on the job finding rate. An increase of the unemployment rate over the spell of unemployment further reduces the job finding rate. The effects occur both the native and the non-western 
immigrant unemployed workers. However, the cyclical sensitivity of job finding rates does not differ between natives and non-western immigrants. In combination our findings suggest that the Great Recession did not have a different impact on the unemployment of non-western immigrants and natives. 


\section{References}

Algan, Y., C. Dustmann, A. Glitz, and A. Manning (2010). The economic situation of first and second-generation immigrants in France, Germany and the United Kingdom. Economic Journal 120, F4-F30.

Bisin, A., E. Patacchini, T. Verdier, and Y. Zenou (2011). Ethnic identity and labour market outcomes of immigrants in Europe. Economic Policy 26, 57-92.

Boeri, T. and J. C. van Ours (2013). The economics of imperfect labor markets, second edition. Princeton University Press.

Cortes, K. (2006). The effects of age at arrival and enclave schools on the academic performance of immigrant children. Economics of Education Review 25, 121-132.

Damm, A. (2009). Ethnic enclaves and immigrant labor market outcomes: Quasiexperimental evidence. Journal of Labor Economics 27, 281-314.

Dustmann, C., T. Frattini, and G. Lanzara. (2012). Educational achievement of second generation immigrants: an international comparison. Economic Policy 69, 143-185.

Dustmann, C. and A. Glitz (2011). Migration and education. In E. A. Hanushek, S. Machin, and L. Woessmann (Eds.), Handbook of The Economics of Education, Volume 4, pp. 327 - 439. Amsterdam: Elsevier.

Dustmann, C., A. Glitz, and T. Vogel (2010). Employment, wages, and the economic cycle: Differences between immigrants and natives. European Economic Review 54, $1-17$.

Edin, P., P. Fredriksson, and O. Aslund (2003). Ethnic enclaves and the economic success of immigrants. Quarterly Journal of Economics 118, 329-357.

OECD (2011). International Migration Outlook. Paris: OECD.

Ohinata, A. and J. C. van Ours (2012). Young immigrant children and their educational attainment. Economics Letters 116, 288-290.

Van Ours, J. C. (2012). The Dutch labour market: Great recession - small impact. CESifo DICE Report 10(2), 20-26.

Van Ours, J. C. and J. Veenman (2003). The educational attainment of second-generation immigrants in the Netherlands. Journal of Population Economics 16, 739-753.

Van Ours, J. C. and J. Veenman (2004). From parent to child: early labor market experiences of second-generation immigrants in the Netherlands. De Economist 152, 473-490.

Van Ours, J. C. and J. Veenman (2005). The Netherlands: Old emigrants-young immigrant country. In K. Zimmermann (Ed.), European migration: what do we know?, pp. 173-196. Oxford University Press.

Van Ours, J. C. and J. Veenman (2006). Age at immigration and educational attainment of young immigrants. Economics Letters 90, 310-316. 


\section{Appendix: Information on the LISS data}

\section{Definition of variables}

- Non-western immigrant: Dummy variable if an individual is a non-western immigrant (first generation or second generation); reference group: natives. For some individuals the immigrant status is unknown. Western immigrants are from a country in Europe (excl. Turkey), North America, Oceania, Indonesia or Japan. Immigrants with a non-western foreign background are from Turkey or countries in Africa, Latin America and Asia, with the exception of Indonesia and Japan. In some estimates additional dummy variables for western immigrants and workers with an unknown immigrant status are included.

- Education: Dummy variables for intermediate vocational, higher vocational and university education; reference group: less than intermediate vocational education.

- Children: Dummy variables if the individual has 1 child, or 2 or more children; reference group: no children.

- Men: Dummy variable if an individual is a man; reference group: women.

- Urbanization: Dummy variables based on population density $\left(\right.$ per $\mathrm{km}^{2}$ ) of the place of residence of an individual: very urban (1500 - 2000), moderately urban (10001500), slightly urban (500-1000), not urban (less than 500); reference group: extremely urban (2500 or more).

- Unemployment rate: Monthly unemployment rate at the national level.

- A person was considered to be employed if one of the following answers was selected: paid employment, works or assists in family business, autonomous professional, freelancer, or self-employed.

- The following situations were treated as state of unemployment: job seeker following job loss, first-time job seeker, exempted from job seeking following job loss, performs unpaid work while retaining unemployment benefit, or performs voluntary work.

\section{Descriptive statistics}

The top part of Table 4 lists descriptive statistics of the LISS panel for the analysis of the monthly data. In total we have 429,243 monthly observations of 12,090 individuals. 
In this sample $7 \%$ of the observations are on non-western immigrants, $57 \%$ on natives, $8 \%$ on western immigrants and $28 \%$ of individuals with an other including unknown immigrant status. The mean age of the individuals is 42.6 , while $53 \%$ of them are males. On average $8 \%$ of the person-month observations refer to an unemployment spell. The average national unemployment rate of the sample period was $5.3 \%$.

The bottom part of Table 4 shows descriptive statistics of the dataset used in the duration analysis. We observe information about 1134 unemployment durations that started during the sample period. Of these unemployment spells, $12 \%$ referred to nonwestern immigrants and $60 \%$ to natives. This part of the table also provides information on the distribution of the sample over educational categories, presence of children, age categories and urbanization categories. The average length of the unemployment spell was 9.6 months, while $54 \%$ of the spells ended because a job was found. Half of the sample consists of unemployment durations of males. 
a. Effect national unemployment rate on probability to be unemployed

\begin{tabular}{|c|c|c|c|}
\hline Average effect & $0.72(8.2)^{* *}$ & $0.84(7.5)^{* *}$ & $0.60(5.3)^{* *}$ \\
\hline \multicolumn{4}{|l|}{ By immigrant status } \\
\hline Natives & $0.77(6.7)^{* *}$ & $0.77(6.7)^{* *}$ & $0.51(4.4)^{* *}$ \\
\hline Non-western immigrants & $1.64(3.4)^{* *}$ & $1.64(3.4)^{* *}$ & $1.51(3.0)^{* *}$ \\
\hline Western immigrants & $0.73(2.0)^{* *}$ & & \\
\hline Unknown & $0.35(2.7)^{* *}$ & & \\
\hline \multicolumn{4}{|c|}{ b. Probability to be unemployed (\%) } \\
\hline Average & 7.5 & 7.6 & 5.4 \\
\hline \multicolumn{4}{|l|}{ By immigrant status } \\
\hline Natives & 6.2 & 6.2 & 3.8 \\
\hline Non-western immigrants & 17.8 & 17.8 & 16.2 \\
\hline Western immigrants & 10.4 & & \\
\hline Unknown & 6.6 & & \\
\hline \multicolumn{4}{|c|}{ c. Relative effect of a 1\%-point increase in national unemployment rates ( $\%$} \\
\hline Average effect & 9.6 & 11.1 & 11. 1 \\
\hline \multicolumn{4}{|l|}{ By immigrant status } \\
\hline Natives & 12.4 & 12.4 & 13.4 \\
\hline Non-western immigrants & 9.2 & 9.2 & 9.3 \\
\hline Western immigrants & 7.0 & & \\
\hline Unknown & 6.6 & & \\
\hline Observations & 429,243 & 276,871 & 210,235 \\
\hline Persons & 12,090 & 6,754 & 5,342 \\
\hline \multicolumn{4}{|c|}{ Columns (1) and (2) age 15 to 64 years; column (3) age $25-54$ years. } \\
\hline \multicolumn{4}{|c|}{ All estimates in panel a include individual fixed effects. } \\
\hline \multicolumn{4}{|c|}{ Absolute $t$ statistics based on robust standard errors in parentheses } \\
\hline${ }^{*} p<0.10,{ }^{* *} p<0.05$ & & & \\
\hline
\end{tabular}




\begin{tabular}{|c|c|c|c|}
\hline & $(1)$ & $(2)$ & $(3)$ \\
\hline \multicolumn{4}{|l|}{ a. Baseline estimates } \\
\hline Non-western immigrant & & $-3.43(2.7)^{* *}$ & $-4.53(3.2)^{* *}$ \\
\hline Unemployment inflow & $-0.23(4.9)^{* *}$ & & \\
\hline Unemployment inflow natives & & $-0.27(4.4)^{* *}$ & $-0.29(4.1)^{* *}$ \\
\hline Unemployment inflow NW immigrants & & $0.20(0.9)$ & $0.36(1.5)$ \\
\hline Unemployment outflow & $-0.37(6.0)^{* *}$ & & \\
\hline Unemployment outflow natives & & $-0.51(6.9)^{* *}$ & $-0.63(7.8)^{* *}$ \\
\hline Unemployment outflow NW immigrants & & $-0.51(1.7)^{*}$ & $-0.49(1.5)$ \\
\hline Intermediate vocational & $0.29(3.0)^{* *}$ & $0.24(2.0)^{* *}$ & $0.16(1.2)$ \\
\hline Higher vocational & $0.45(4.5)^{* *}$ & $0.39(3.9)^{* *}$ & $0.12(0.8)$ \\
\hline University & $0.32(2.1)^{* *}$ & $0.50(2.6)^{* *}$ & $0.41(1.9)^{*}$ \\
\hline 1 child & $-0.17(1.5)$ & $-0.12(0.9)$ & $-0.07(0.5)$ \\
\hline 2 or more children & $0.12(1.2)$ & $0.21(1.9)^{*}$ & $0.28(2.2)^{* *}$ \\
\hline Men & $0.10(1.2)$ & $0.04(0.4)$ & $-0.05(0.4)$ \\
\hline Age $17-24$ & $-0.07(0.5)$ & $0.08(0.5)$ & \\
\hline Age $35-44$ & $-0.32(2.9)^{* *}$ & $-0.28(2.1)^{* *}$ & $-0.36(2.6)^{* *}$ \\
\hline Age $45-54$ & $0.56(3.8)^{* *}$ & $0.58(3.4)^{* *}$ & $0.46(3.2)^{* *}$ \\
\hline Age 55-64 & $-1.01(7.2)^{* *}$ & $-1.13(6.7)^{* *}$ & \\
\hline Months 4-6 & $-0.11(1.1)$ & $0.00(0.0)$ & $0.01(0.1)$ \\
\hline Months 7-9 & $-0.39(3.1)^{* *}$ & $-0.16(1.2)$ & $-0.13(0.8)$ \\
\hline Months 10-12 & $-0.76(4.5)^{* *}$ & $-0.56(2.8)^{* *}$ & $-0.46(2.1)^{* *}$ \\
\hline Months 13-18 & $-0.94(5.6)^{* *}$ & $-0.62(3.3)^{* *}$ & $-0.50(2.3)^{* *}$ \\
\hline Months 18+ & $-1.39(5.3)^{* *}$ & $-1.18(3.7)^{* *}$ & $-1.12(2.9)^{* *}$ \\
\hline Constant & $-0.88(3.1)^{* *}$ & $-0.56(1.5)$ & $-0.36(0.9)$ \\
\hline -Loglikelihood & 2067.0 & 1497.5 & 1077.6 \\
\hline \multicolumn{4}{|l|}{ b. Imposing restrictions } \\
\hline Non-western immigrant & & $-0.86(5.8)^{* *}$ & $-0.93(5.7)^{* *}$ \\
\hline Unemployment inflow & & $-0.24(4.1)^{* *}$ & $-0.24(3.5)^{* *}$ \\
\hline Unemployment outflow & & $-0.51(7.2)^{* *}$ & $-0.62(7.9)^{* *}$ \\
\hline -Loglikelihood & & 1499.4 & 1080.5 \\
\hline LR-test statistic & & 3.8 & $5.8^{*}$ \\
\hline Observations & 1134 & 816 & 559 \\
\hline
\end{tabular}

Note that all estimates also contain 4 dummy variables indicating degree of urbanization;

Also note that panel $\mathrm{b}$ estimates also contain the same explanatory variables as panel a; In panel $\mathrm{b}$ the cyclical effects are imposed to be equal for natives and immigrants.

Absolute $t$-statistics in parentheses; ${ }^{*} p<0.10,{ }^{* *} p<0.05$ 
Table 3: Hazard Rates Estimates; Sensitivity Analysis

\begin{tabular}{|c|c|c|c|}
\hline & \multicolumn{2}{|c|}{$\overline{\mathrm{PH} \text { model }}$} & \multirow[b]{2}{*}{$\begin{array}{c}\text { MPH model } \\
(3)\end{array}$} \\
\hline & $\begin{array}{l}\text { Men } \\
(1)\end{array}$ & $\begin{array}{c}\text { Women } \\
(2)\end{array}$ & \\
\hline \multicolumn{4}{|l|}{ a. Sensitivity analysis } \\
\hline Non-western immigrant & $-2.56(1.3)$ & $-4.23(2.7)^{* *}$ & $-4.00(3.0)^{* *}$ \\
\hline Unemployment inflow natives & $-0.32(3.2)^{* *}$ & $-0.21(2.7)^{* *}$ & $-0.28(4.0)^{* *}$ \\
\hline Unemployment inflow NW immigrants & $0.06(0.2)$ & $0.34(1.3)$ & $0.29(1.3)$ \\
\hline Unemployment outflow natives & $-0.90(8.6)^{* *}$ & $-0.20(1.3)$ & $-0.56(7.1)^{* *}$ \\
\hline Unemployment outflow NW immigrants & $-0.85(1.8)^{*}$ & $-0.19(0.9)$ & $-0.81(2.4)^{* *}$ \\
\hline -Loglikelihood & 719.4 & 755.4 & 1493.6 \\
\hline \multicolumn{4}{|l|}{ b. Imposing restrictions } \\
\hline Non-western immigrant & $-0.47(2.2)^{* *}$ & $-1.22(5.6)^{* *}$ & $-0.94(5.9)^{* *}$ \\
\hline Unemployment inflow & $-0.29(3.0)^{* *}$ & $-0.18(2.3)^{* *}$ & $-0.24(3.7)^{* *}$ \\
\hline Unemployment outflow & $-0.88(8.5)^{* *}$ & $-0.21(1.5)$ & $-0.58(7.6)^{* *}$ \\
\hline -Loglikelihood & 720.0 & 756.7 & 1496.3 \\
\hline LR-test statistic & 1.2 & 2.6 & $5.4^{*}$ \\
\hline Observations & 386 & 430 & 816 \\
\hline
\end{tabular}

Columns (1) and (2) age 15 to 64 years; column (3) age 25-54 years.

Note that all estimates also contain the same explanatory variables as Table 2.

In panel $\mathrm{b}$ the cyclical effects are imposed to be equal for natives and immigrants.

Absolute $t$-statistics in parentheses; ${ }^{*} p<0.10,{ }^{* *} p<0.05$ 


\begin{tabular}{|c|c|c|c|}
\hline & Mean & Min. & Max \\
\hline \multicolumn{4}{|c|}{ a. Monthly Data - 429,243 observations of 12,090 individuals } \\
\hline \multicolumn{4}{|l|}{ Immigrant status } \\
\hline Native & 0.57 & 0 & 1 \\
\hline Non-western immigrant & 0.07 & 0 & 1 \\
\hline Western immigrant & 0.08 & 0 & 1 \\
\hline Unknown & 0.28 & 0 & 1 \\
\hline Age & 42.6 & 16 & 64 \\
\hline Male & 0.53 & 0 & 1 \\
\hline Unemployment & 0.08 & 0 & 1 \\
\hline Unemployment rate & 5.3 & 3.4 & 7.5 \\
\hline \multicolumn{4}{|c|}{ b. Unemployment Spells - 1134 observations } \\
\hline \multicolumn{4}{|l|}{ Immigrant status } \\
\hline Non-western immigrant & 0.12 & 0 & 1 \\
\hline Native & 0.60 & 0 & 1 \\
\hline Other including unknown & 0.28 & 0 & 1 \\
\hline \multicolumn{4}{|l|}{ Education } \\
\hline Reference & 0.42 & 0 & 1 \\
\hline Intermediate vocational & 0.29 & 0 & 1 \\
\hline Higher vocational & 0.20 & 0 & 1 \\
\hline University & 0.09 & 0 & 1 \\
\hline \multicolumn{4}{|l|}{ Children } \\
\hline No & 0.54 & 0 & 1 \\
\hline 1 child & 0.17 & 0 & 1 \\
\hline 2 or more children & 0.29 & 0 & 1 \\
\hline \multicolumn{4}{|l|}{ Age } \\
\hline $17-24$ & 0.13 & 0 & 1 \\
\hline $25-34$ & 0.22 & 0 & 1 \\
\hline $35-44$ & 0.26 & 0 & 1 \\
\hline $45-54$ & 0.21 & 0 & 1 \\
\hline $55-64$ & 0.39 & 0 & 1 \\
\hline \multicolumn{4}{|l|}{ Urbanization } \\
\hline Extremely urban & 0.21 & 0 & 1 \\
\hline Very urban & 0.31 & 0 & 1 \\
\hline Moderately urban & 0.21 & 0 & 1 \\
\hline Slightly urban & 0.16 & 0 & 1 \\
\hline Not urban & 0.11 & 0 & 1 \\
\hline Unemployment duration (months) & 9.6 & 1 & 61 \\
\hline Job finding & 0.54 & 0 & 1 \\
\hline Male & 0.50 & 0 & 1 \\
\hline
\end{tabular}


a. Age 15-24

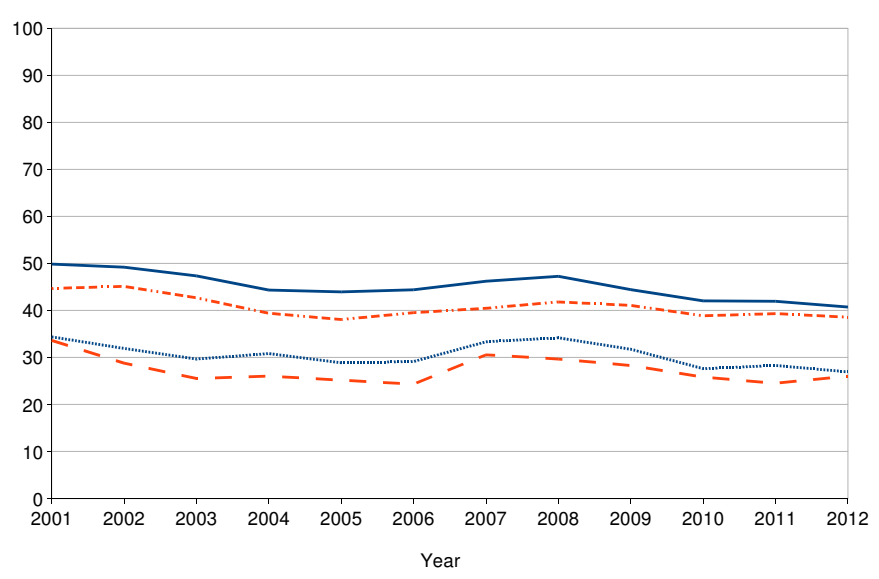

\section{b. Age $25-54$}

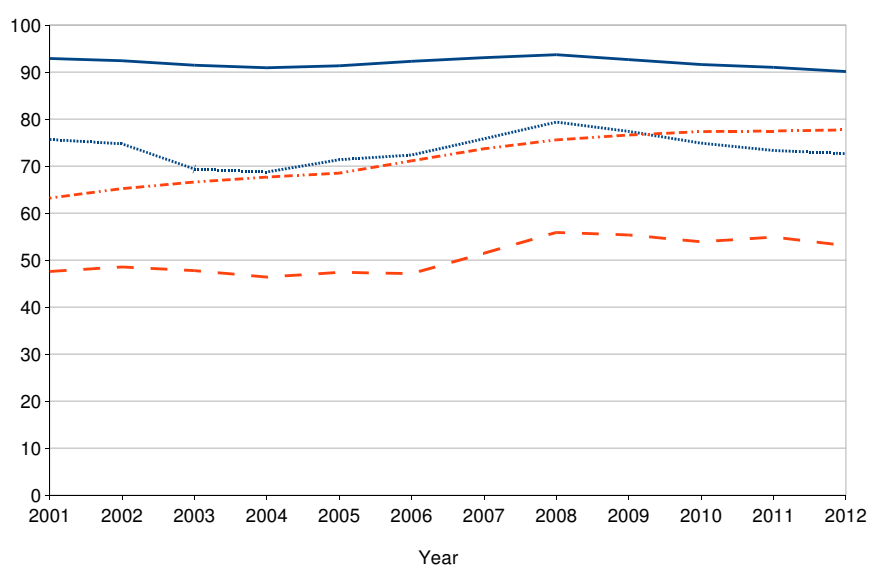

c. Age 55-64

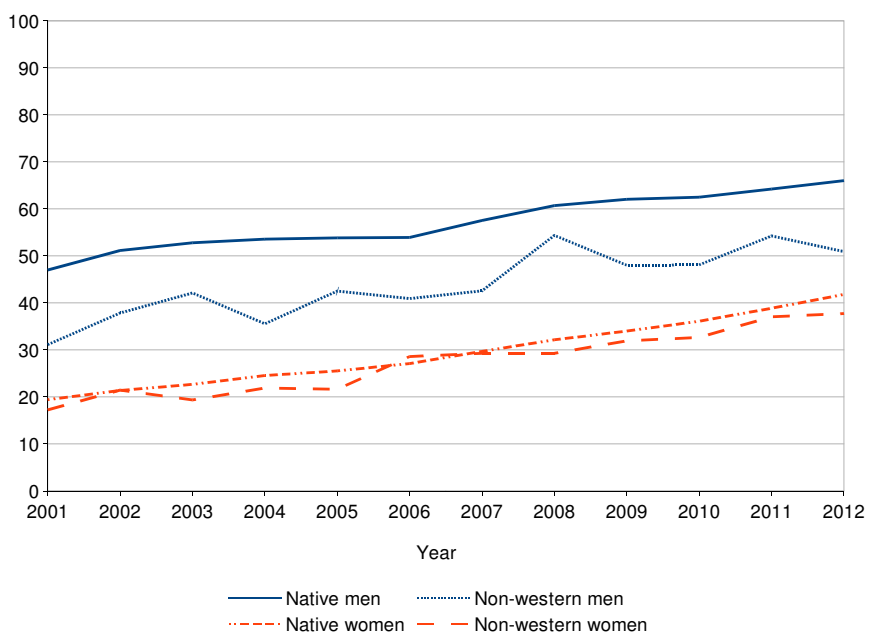

Figure 1: Annual Employment Rates by Age Group; 2001 - 2012 Source: Statistics Netherlands and own calculations 
a. Age 15-24

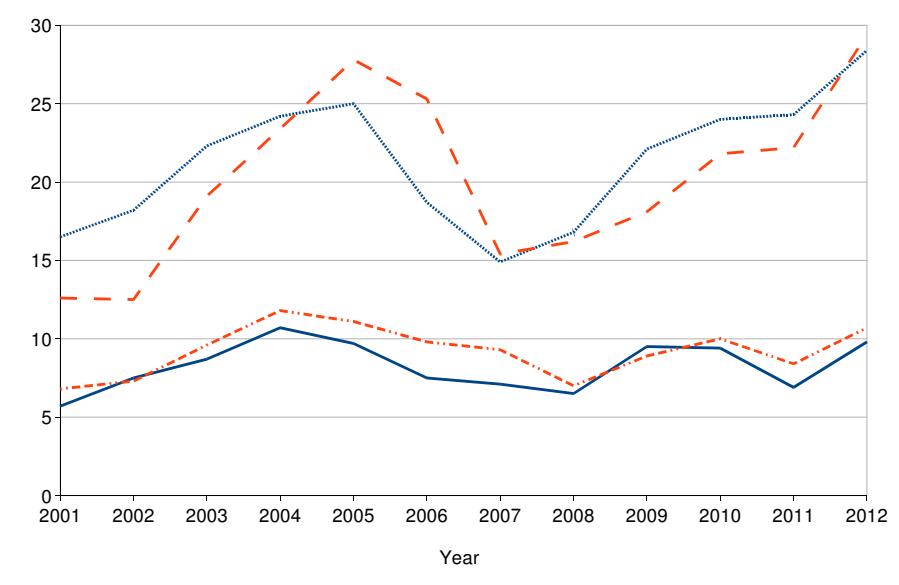

b. Age 25-54

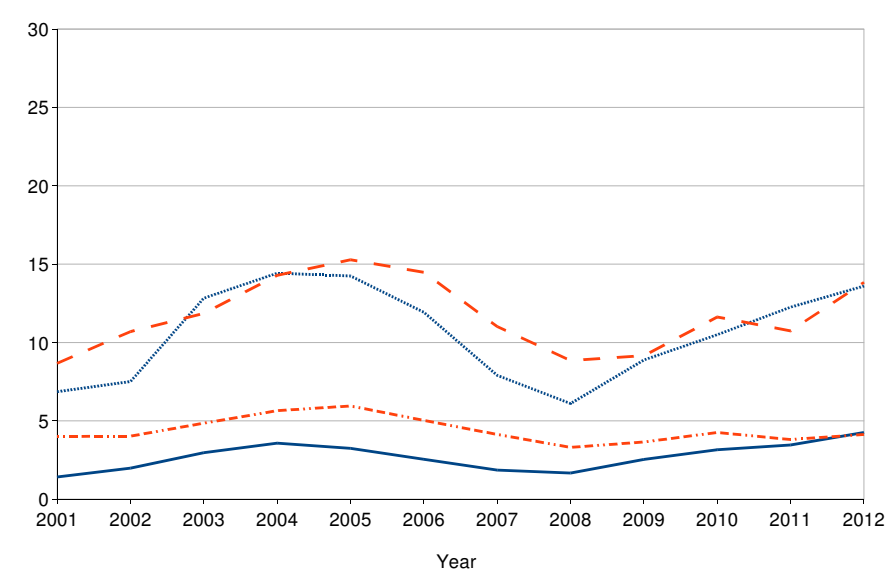

c. Age 55-64

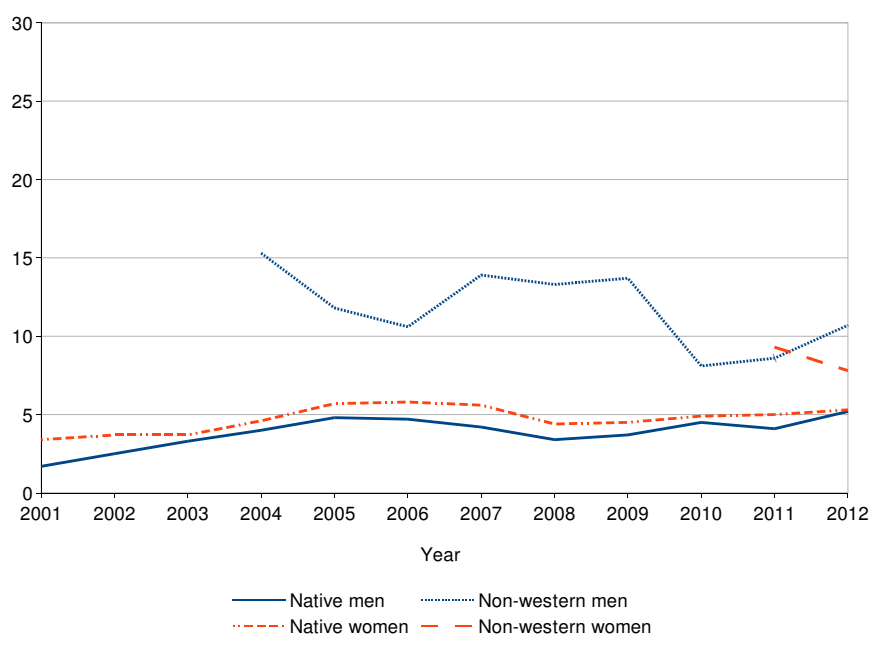

Figure 2: Annual Unemployment Rates by Age Group; 2001 - 2012 Source: Statistics Netherlands and own calculations 


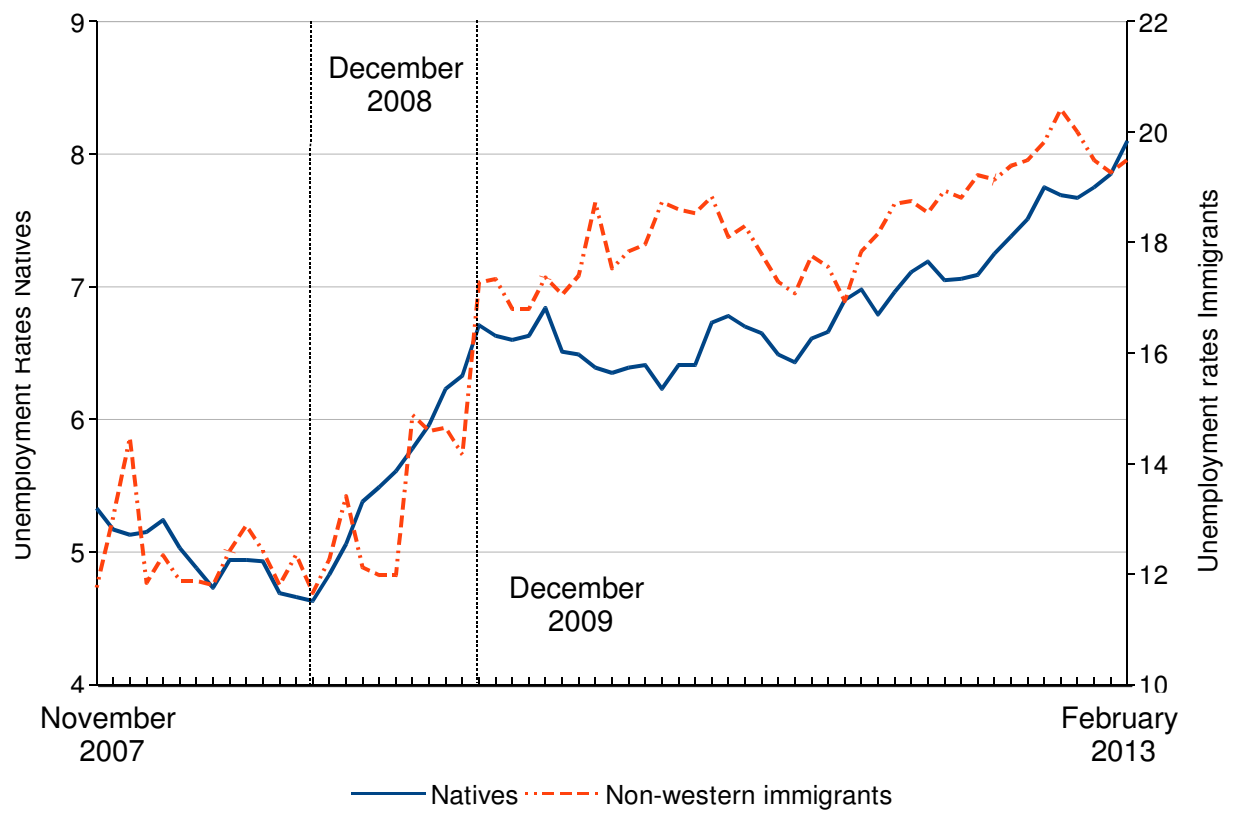

Figure 3: Monthly Unemployment Rates in the LISS-panel; November 2007 - February 2013 
a. Job finding rates

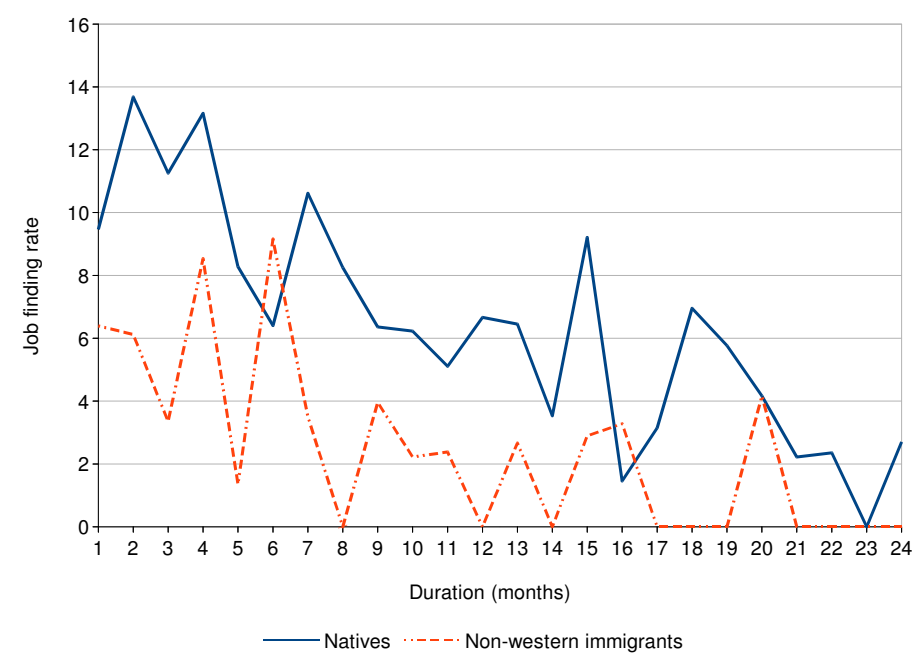

b. Unemployment survival probabilities

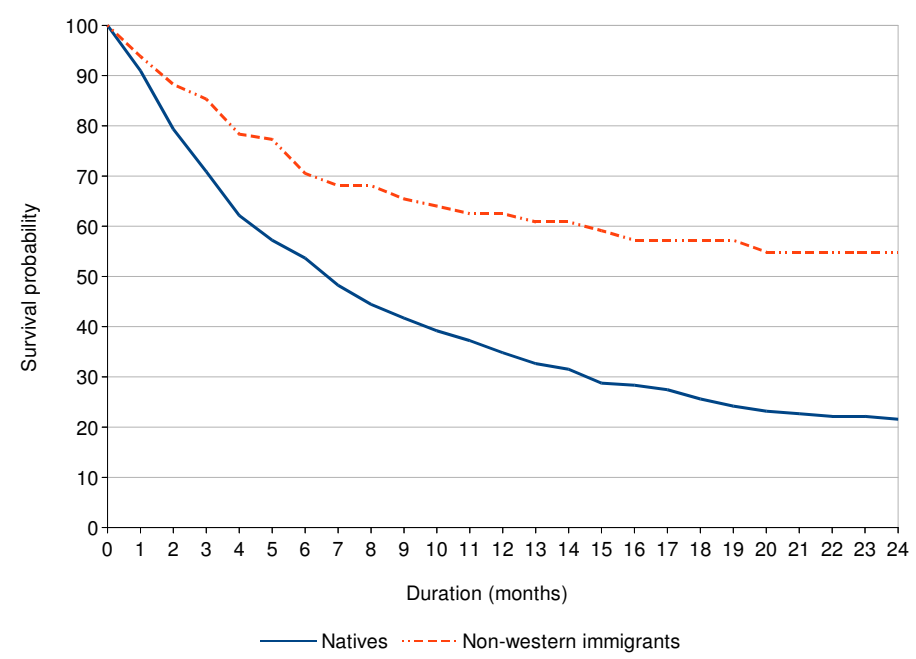

Figure 4: Job Finding Rates and Unemployment Survival Probabilities Prime Age Workers 


\section{University Library}

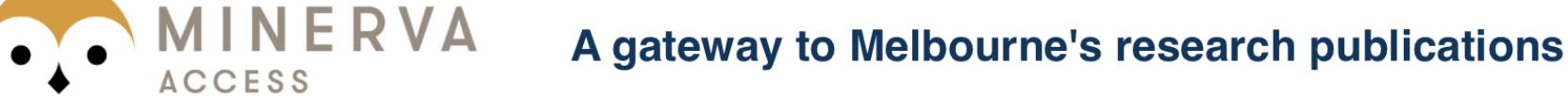

Minerva Access is the Institutional Repository of The University of Melbourne

Author/s:

Cerveny, J;van Ours, JC

Title:

Unemployment of Non-Western Immigrants in the Great Recession

Date:

2013-12-01

Citation:

Cerveny, J. \& van Ours, J. C. (2013). Unemployment of Non-Western Immigrants in the Great Recession. ECONOMIST-NETHERLANDS, 161 (4), pp.463-480. https:// doi.org/10.1007/s10645-013-9216-2.

Persistent Link:

http://hdl.handle.net/11343/282563 